\title{
Pleomorphic high-grade sarcoma of the heart mimicking cardiac myxoma
}

\author{
Benjamin Etschmann, ${ }^{1}$ Gabriele Krombach, ${ }^{1}$ Andreas Böning, ${ }^{2}$ Stefan Gattenlöhner ${ }^{1}$ \\ ${ }^{1}$ University of Giessen, Institute of Pathology, Giessen, Germany; \\ 2University of Giessen, Department of Thoracic and Heart Surgery, Giessen, Germany
}

Correspondence to Professor Stefan Gattenlöhner, stefan.gattenloehner@patho.med.uni-giessen.de

\section{DESCRIPTION}

A 22-year-old male patient with no significant previous medical history presented with fatigue, dyspnoea, palpitations and signs of upper inflow tract congestion. Echocardiography (figure $1 \mathrm{a}$ ) and CT revealed a mass of $4 \times 6 \mathrm{~cm}(*)$ in the left atrium which prolapsed into the left ventricle during diastole and displayed radiological and ultrasonographic traits of an atrial myxoma (sharp borders, pedunculated appearance, mobility during cardiac cycle, localisation in left atrium, lack of detectable infiltration into cardiac/pericardiac structures). Histopathological examination of the surgically excised mass revealed a myxoid tissue structure low in cell count (figure $1 \mathrm{~b}$ ) with multilayered perivascular cell agglomerates resembling myxoma ring structures (figure $1 \mathrm{~b}$ inset). However, the perivascular cells involved were strikingly large and other domains of the extirpated tumour corresponded to a pleomorphic spindle cell neoplasia (figure 1c) with elevated nuclear polymorphism, mitosis rate (arrows) and proliferation (MIB1-immunostaining, figure $1 \mathrm{c}$ inset) as well as immunohistochemical positivity for actin, vimentin and partially for keratin (not shown). As postoperative tumour staging ruled out the presence of a primary extracardiac neoplasia, a primary pleomorphic epitheloid high-grade sarcoma of the heart (G3) was diagnosed (reference pathological confirmation by Professor C Fletcher, Harvard Medical School). Further postoperative staging revealed multiple lytic bone lesions (figure $1 \mathrm{~d}$ arrows), which were confirmed

a
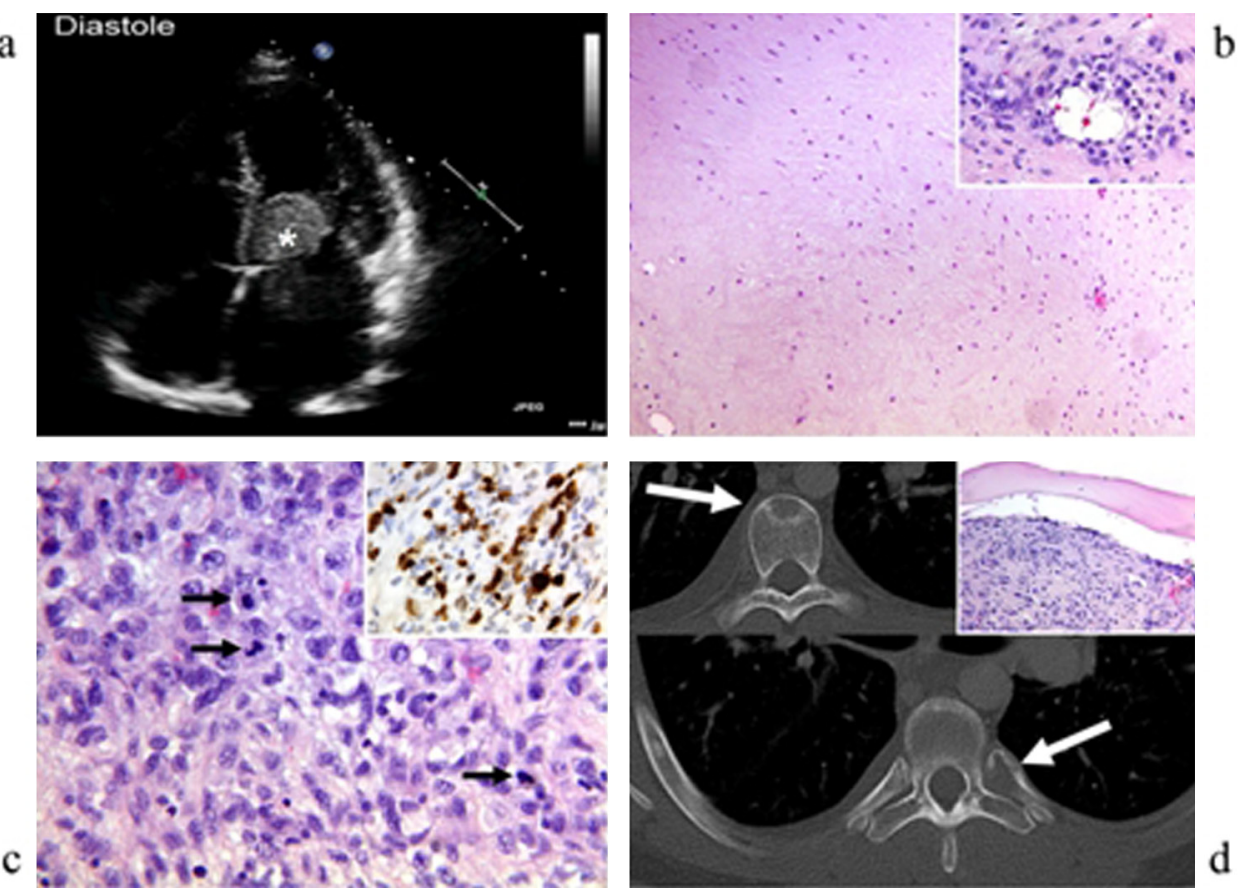

Figure 1 (a) Echocardiography of the heart revealing a tumour mass in the left atrium which prolapses into the left ventricle during diastole (highlighted by ${ }^{*}$ ). (b) Histopathological image of extirpated tumour mass showing myxoid tumour areas with low cell count and multi-layered agglomerates of large, pleomorphic cells around blood vessels (inset). H\&E-stain. Magnification: 20x (main image), 40x (inset). (c) Histopathological image of extirpated tumour mass exhibiting a pleomorphic spindle cell neoplasia with markedly elevated nuclear polymorphism, mitosis rate (arrows) and proliferation (MIB1 staining, inset). H\&E-stain (main image) and MIB1 immunohistochemistry (inset). Magnification: 60x (main image), 40x (inset). (d) CT scan of the spine showing multiple lytic lesions (arrows) and histopathological identification of punch biopsy samples from bone lesions as metastases of a pleomorphic high-grade sarcoma (inset). H\&E-stain (inset). Magnification: 20x (inset). 


\section{BMJ Case Reports}

as sarcoma metastases (figure $1 \mathrm{~d}$ inset). Malignant cardiac sarcomas show a tendency toward myxoid degeneration. ${ }^{12}$ Therefore, in case of preoperative doubt, particularly diligent clinical and histopathological scrutiny of suspicious cardiac tumours is advisable and should be augmented by further imaging examinations as well as tumour staging procedures.

\section{Learning points}

- Cases diagnosed as cardiac myxoma should be particularly diligently worked up in order to rule out the presence of cardiac sarcoma with myxoid degeneration.
Acknowledgements The authors would like to thank Nicole Neuhaus for expert technical assistance.

Competing interests None.

Patient consent Obtained.

\section{REFERENCES}

1. Puppala S, Hoey ET, Mankad K, et al. Primary cardiac angiosarcoma arising from the interatrial septum: magnetic resonance imaging appearances. $\mathrm{Br} J$ Radio/ 2010;83:e230-4

2. Yokouchi Y, Hiruta N, Oharaseki T, et al. Primary cardiac synovial sarcoma: a case report and literature review. Pathol Int 2011;61:150-5.

This pdf has been created automatically from the final edited text and images.

Copyright 2012 BMJ Publishing Group. All rights reserved. For permission to reuse any of this content visit

http://group.bmj.com/group/rights-licensing/permissions.

BMJ Case Report Fellows may re-use this article for personal use and teaching without any further permission.

Please cite this article as follows (you will need to access the article online to obtain the date of publication).

Etschmann B, Krombach G, Böning A, Gattenlöhner S. Pleomorphic high-grade sarcoma of the heart mimicking cardiac myxoma. BMJ Case Reports 2012;10.1136/bcr.12.2011.5277, Published XXX

Become a Fellow of BMJ Case Reports today and you can:

- Submit as many cases as you like

- Enjoy fast sympathetic peer review and rapid publication of accepted articles

- Access all the published articles

- Re-use any of the published material for personal use and teaching without further permission

For information on Institutional Fellowships contact consortiasales@bmjgroup.com

Visit casereports.bmj.com for more articles like this and to become a Fellow

Keep up to date with all published cases by signing up for an alert (all we need is your email address) http://casereports.bmj.com/cgi/alerts/etoc 